\section{Transplantasjon av luftrør}

Den første transplantasjonen av et vevsgenerert (tissue-engineered) luftrør var en suksess og har gitt en drastisk bedring i mottakerens livskvalitet. Resultatene av transplantasjonen er e-publisert i The Lancet (DOI: 10.1016/S0140-6736(08)61598-6).

Forskerne fjernet cellene fra en trachea fra en donor, for å unngå avvisning av transplantatet. Deretter ble trachea kolonisert med epitelceller og stamceller fra mottakeren. Transplantatet erstattet pasientens venstre hovedbronkie. Pasienten hadde ingen komplikasjoner etter operasjonen og ble utskrevet fra sykehuset ti dager senere.

\section{Trombolytisk behandling ved akutt lungeemboli}

Få av dem som var innlagt med akutt lungeemboli fikk trombolytisk behandling, det viser en analyse fra 186 akuttsykehus i Pennsylvania (Arch Intern Med 2008; 168 : 2183-90).

Av mer enn 15000 pasienter fikk kun 356 $(2,4 \%)$ slik terapi. Mortalitetsraten etter 30 dager var $17,4 \%$ for dem som fikk trombolytisk behandling, mot 8,6\% for dem som ikke fikk. Mortalitetsrisikoen etter 30 dager var økt for pasienter som ikke var sannsynlige kandidater for trombolytisk behandling, men ikke for dem med høy sannsynlighet for å få slik terapi.

\section{Distribusjon av malarianett i Afrika}

Dekning og distribusjon av malarianett i Afrika er fortsatt dårlig. Det er konklusjonen i en studie i The Lancet, der man har sett på malarianettdistribusjon i 40 malariaendemiske land i perioden 2000-07 (DOI: 10.1016/S0140-6736(08)61596-2).

Forfatterne estimerte dekningen hos barn under fem år. I 2000 var kun 1,7 millioner afrikanske barn $(1,8 \%)$ beskyttet med malarianett, i 2007 hadde dette økt til 20,3 millioner (18,5\%). Omtrent 90 millioner barn er fortsatt ubeskyttet, og hele $25 \%$ av disse bor i Nigeria. 33 land ( $83 \%$ ) hadde en malarianettdekning på < $40 \%$ i 2007. Det var en større økning i dekning i områder hvor det hadde vært gratis distribusjon av malarianett i årene 2000-07.

\title{
Påvirker sår tumorvekst?
}

\section{En amerikansk forskningsgruppe har i musestudier undersøkt om sår og sårtilheling påvirker tumorvekst i brystet.}

Stikk eller kirurgiske prosedyrer blir benyttet i forbindelse med diagnostisering og behandling av brystkreft. Dette medfører sår og sårtilheling $\mathrm{i}$ brystet. Resultater fra museforsøk tyder på at sårtilheling fører til akselerert tumorvekst (1).

Mus med brystkreft ble påført sår $i$ brystregionen eller på ryggen, og tumorveksten ble sammenliknet med svulster hos kontrollmus uten sår. Forskerne fant at sår i brystet førte til akselerert vekst av svulsten. Sår lenger unna svulsten hadde ingen effekt på tumorveksten. Også ved å injisere sårvæske nær svulsten oppnådde man tumorvekst hos musene. Effekten så ut til å være T-celleavhengig, ettersom forsøk på mus uten funksjonelle T-celler ikke medførte økt tumorvekst.

- Operasjon er den mest effektive behandling av brystkreft. Men en operasjon vil kunne fremme muligheten for tumorvekst og metastasering - ved mekanisk frisetting av kreftceller, stimulering av angio- genesen, frigjøring av vekstfaktorer og immunsuppresjon, sier avdelingsoverlege Ellen Schlichting ved Bryst- og endokrinkirurgisk avdeling, Ullevål universitetssykehus.

- Noen pasienter nevner at svulsten er blitt større etter prøvetaking med fin- eller grovnål. Hematomutvikling i forbindelse med prøvetakingen kan gjøre det vanskelig å vurdere om det har vært en reell tumorvekst. I tillegg er det oftest et kort tidsintervall mellom prøvetaking og operasjon. Det er i humane studier ikke vist økt residivhyppighet i relasjon til utredningsmetode med henholdsvis fin- eller grovnål eller antall inngrep ved brystkreft. Én grunn til at vi ikke ser det ved brystkreft, kan være at svulsten med stikkanal senere opereres bort og at det hos mange pasienter i tillegg gis strålebehandling mot det opererte området, sier Schlichting.

\section{Åslaug Helland}

aslaug.helland@gmail.com

Tidsskriftet

\section{Litteratur}

1. Stuelten $\mathrm{CH}$, Barbul A, Busch Jl et al. Acute wounds accelerate tumorigenesis by a T-celldependent mechanism. Cancer Res 2008; 68 7278-82.

\section{B-vitaminer forebygger ikke kreft}

\section{Tilskudd av folat, vitamin $\mathrm{B}_{6}$ og vita- min $B_{12}$ endrer ikke forekomsten av kreft. Det viser en stor randomisert studie med amerikanske kvinner.}

B-vitaminer er viktige for DNA-syntese og metylering, og det kan derfor tenkes at de spiller en kreftforebyggende rolle. Den amerikanske WAFAC-studien (Women's Antioxidant and Folic Acid Cardiovascular Study) ble opprinnelig designet for å undersøke effekten av kombinert B-vitamintilskudd på risikoen for nye kardiovaskulære hendelser hos kvinner over 42 år som enten hadde kardiovaskulær sykdom eller flere kardiovaskulære risikofaktorer.

5442 kvinner ble randomisert til enten placebo eller et daglig tilskudd av en kombinasjon av folat, vitamin $\mathrm{B}_{6}$ og vitamin $\mathrm{B}_{12}$ over en observasjonstid på 7,3 år. Nå viser en detaljert analyse av kreftendepunktene i denne studien at risikoen for å utvikle invasiv kreft eller brystkreft var den samme i placebogruppen og behandlingsgruppen (1).

- Dette er den første store studien der man ser detaljert på kreftforekomsten under langvarig inntak av folat $\mathrm{i}$ store doser på 2,5 mg. Resultatet er beroligende ut fra den bekymring for vekststimulering av maligne tilstander som har vært reist i forbindelse med bruk av folattilskudd og beriking av matvarer med folat for å forebygge nevralrørsdefekter. For eksempel er melet i USA, Canada og Chile og mange andre ikkeeuropeiske land tilsatt folat, sier professor Stein Emil Vollset ved Universitetet i Bergen og Nasjonalt folkehelseinstitutt.

- Studien er en av mange negative studier på tilskudd med B-vitaminer til pasienter med hjerte- og karsykdom. For de enkelte krefttyper er tallene i denne studien relativt små. Det forventes at en rekke liknende studier med fokus på kreft vil bli publisert de nærmeste årene, også fra Norge, sier Vollset.

\section{Are Brean}

are.brean@siv.no

Tidsskriftet

\footnotetext{
Litteratur

1. Zhang SM, Cook NR, Albert CM et al. Effect of combined folic acid, vitamin B6, and vitamin B12 on cancer risk in women: a randomized trial. JAMA 2008; 300: 2012-21.
} 